\title{
Clinical and laboratory predictors of early mortality in patients with acute myocardial infarction treated with primary percutaneous coronary intervention
}

\author{
Dušan P. Ružičić ${ }^{1}$, Milijana M. Ružičić ${ }^{1}$, Igor B. Mrdović ${ }^{2}$ \\ ${ }^{1}$ General Hospital Valjevo, Department of Internal Medicine - Cardiology, Valjevo, Serbia \\ ${ }^{2}$ Clinical Center of Serbia, Clinic for Emergency Internal Medicine, Department for \\ Cardiology, Belgrade, Serbija
}

\section{SUMMARY}

Introduction: Primary percutaneous coronary intervention $(\mathrm{pPCl})$ has become the preferred reperfusion strategy in patients with ST-elevation myocardial infarction (STEMI). Previous research studies have shown that certain clinical and laboratory parameters can be associated with early mortality in patients with acute myocardial infarction treated by primary $\mathrm{PCl}$.

The Aim: The aim of our study was to determine the clinical and laboratory predictors of an adverse early prognosis of our patients with STEMI treated by primary $\mathrm{PCl}$.

Material and Methods: The population of our IV phase, academic, observational, retrospective cross-sectional study comprises a total of 180 consecutive patients, 128 men and 52 women, aged 18, or older, who presented with clinical and electrocardiographic signs of acute STEMI within 12 hours after symptom onset. We analyzed the parameters which were registered in the database system of the Coronary Unit of Emergency Center.

Results: The average age of the surviving patients was $58 \pm 11$, and $67 \pm 9$ in the deceased patient group but the correlation was not statistically significant $(p=0.075)$. The group of patients who didn't survive had significantly more hypotension on admission $(p=0.015)$, acute bundle branch block on ECG $(p=0.032)$, higher creatinine on admission $(p=0.036)$, patient history of hyperlipidaemia $(p=0.044)$, creatinine clearance below $60 \mathrm{ccs} / \mathrm{min}(p<0.001)$, Killip $>1$ heart failure on admission $(p=0.038)$, but this group contained a significantly lower number of smokers $(p=0.021)$. Predictors of an adverse early event in multivariant analysis were: acute bundle branch block, diabetes, Killip> 1 on admission, hypotension on admission, creatinine clearance below $60 \mathrm{ccs} / \mathrm{min}$.

Conclusions: Our study indicates that acute bundle branch block, diabetes, Killip $>1$ heart failure on admission, hypotension on admission, creatinine clearence below $60 \mathrm{ccs} / \mathrm{min}$, are independent clinical and laboratory predictors of early mortality in patients with STEMI treated by primary $\mathrm{PCl}$.

Keywords: $\mathrm{PCl}$, myocardial infarction, early mortality 


\section{INTRODUCTION}

Primary percutaneous coronary intervention (pPCI) has become the preferred reperfusion strategy in patients with ST-elevation myocardial infarction (STEMI) (STEMI) [1-5]. Compared with thrombolytic and conservative therapy, the application of pPCI reduced the intrahospital and late mortality rate in patients with STEMI, and the frequency of other early or late complications [6].

Studies have shown that there are certain clinical and laboratory indicators of adverse outcome in patients after pPCI $[4,5,6]$. According to some authors' results, independent predictors of intrahospital mortality in patients with STEMI after pPCI are: age (patients older than 75 years), AMI complications with cardiogenic shock, the long time interval from pain onset to pPCI, comorbidities, previous cardiac and renal failure, high glucose levels and other laboratory findings [6-8].

\section{THE AIM}

The aim of our study was to determine the clinical and laboratory predictors that indicate an adverse early prognosis of our patients with STEMI treated by $\mathrm{pPCI}$.

\section{MATERIAL AND METHODS}

Our study is IV phase, academic, observational, retrospective cross-sectional study comprises a total of. The study follows the Good Clinical Practice guidelines and is conducted in accordance with the provisions of the regulation of clinical trials in the Republic of Serbia [9]. The study included 180 consecutive patients who were hospitalized in the Coronary Care Unit of the Emergency Center, Clinical Center of Serbia, over 18 years of age, with clinical and electrocardiographic signs of acute STEMI, which lasted up to 12 hours after the symptom onset.

the study are:

Criteria for inclusion of patients in - patients over the age of 18 ;

- typical precordial pain lasting for more than 20 minutes;

- time period from symptom onset to admission should not exceed 12 hours;

- electrocardiography (ECG): ST elevation in at least two contiguous leads, measuring more than $0.2 \mathrm{mV}$ in leads $\mathrm{V} 2$ and $\mathrm{V} 3$ or more than
$0.1 \mathrm{mV}$ in all other leads or new acute bundle branch block;

- values of cardiac-specific markers (troponin) above the normal reference range (on admission and / or after $24 \mathrm{~h}$ );

Criteria for exclusion from the study: - non-consent by the patient to the invasive treatment;

- contraindications to double-antiaggregation therapy or contrast media: active or recent internal bleeding, previous bleeding after the use of nonsteroidal antiinflammatory drugs, known hemorrhagic diathesis, allergy to contrast, intracranial tumor or aneurysm, platelet count of less than $100000 / \mathrm{mm} 3$ );

- cardiogenic shock on admission;

The access for coronary angiography was via a. femoralis. Primary PCI and stent placement in occluded infarct-related artery (IRA) was performed according to standard techniques (visualization of non-occluded artery/non-infarction-related artery (non-IRA) with diagnostic $6 \mathrm{~F}$ catheter, visualization of the IRA with 6-F guiding catheter, angioplasty and stent placement of anatomically accessible places).

We analyzed the following clinical and laboratory variables recorded in an electronic database of the Emergency Center Coronary Care Unit CCU: age, gender, medical history, and risk factors (previous heart attack, hypertension, hyperlipidemia, diabetes), heart failure according to Killip- $\mathrm{u}>1$ on admission, systolic and diastolic blood pressure, heart rate frequency, hypotension on admission, hemoglobin levels, leukocytes, potassium, platelet count, creatine kinase, fibrinogen, creatinine, creatinine clearance (calculated by CockcroftGault Equation), admission glucose levels, acute bundle branch block, changes on lung $\mathrm{X}$-rayand RTG enlarged cardiac silhouette.

The primary objective of the thesis was the intrahospital mortality.

Following statistical methods were used to process the obtained data: a Student's $\mathrm{t}$-test for numerical variables with the normal data distribution or the Mann-Whitney test for numerical variables without the normal data distribution, $\chi 2$ test or the Ficher test for categorical characteristics and univariate and multivariate logistic regression method. Values of $\mathrm{p}<0.05$ were considered to be significant. 
Table 1. Baseline clinical characteristics of the study groups

* statistically significant difference $(p<0.05)$

Table 2. Baseline laboratory characteristics of the study groups

Hgb - hemoglobin levels

Le - the total number of leukocytes

$\mathrm{K}^{+}$- potassium concentration

$\mathrm{Tr}$ - the total thrombocyte count

p - level of statistical significance

* statistically significant difference $(p<0.05)$

Table 3. Baseline laboratory characteristics of the study groups - Creatinine clearance (Cockcroft-Gault Equation)

p - level of statistical significance $(p<0.05$ statistically significant)

* statistically significant difference $(p<0.05)$

\begin{tabular}{|c|c|c|c|}
\hline & Survivors $(\mathrm{N}=174)$ & Deceased $(\mathrm{N}=6)$ & $\mathrm{p}$ \\
\hline \multicolumn{4}{|c|}{ Demographic data } \\
\hline \multirow{2}{*}{ Gender $(n / N)$} & $123(70.7 \%)$ & $5(83.3 \%)$ & \multirow{2}{*}{0.502} \\
\hline & $51(29.3 \%)$ & $1(16.7 \%)$ & \\
\hline Age \pm SD & $58 \pm 11$ & $67 \pm 9$ & 0.075 \\
\hline \multicolumn{4}{|c|}{ Anamnestic data and risk factors } \\
\hline Previous Myocardial Infarction $\mathrm{n}(\mathrm{n} / \mathrm{N})$ & $27(15.5 \%)$ & $2(33.3 \%)$ & 0.243 \\
\hline Anamnesis hypertension history $(\mathrm{n} / \mathrm{N})$ & $126(72.4 \%)$ & $3(50 \%)$ & 0.231 \\
\hline History of hyperlipidemia (n/N) & $73(41.9 \%)$ & $5(83.3 \%)$ & $0.044^{*}$ \\
\hline Diabetes $(\mathrm{n} / \mathrm{N})$ & $34(19.5 \%)$ & $2(33.3 \%)$ & 0.064 \\
\hline \multicolumn{4}{|c|}{ Physical examination on admission } \\
\hline Killip>1 $(25,75$ per. $)$ & $1(1,1)$ & $1(1,3)$ & $0.038^{*}$ \\
\hline Systolic blood pressure mmHg ( 25,75 per.) & $140(110,170)$ & $120(80,160)$ & 0.140 \\
\hline Diastolic BP mmHg (25, 75 per.) & $90(80,100)$ & $90(58,110)$ & 1.000 \\
\hline Heart rate frequency $(25,75$ per. $)$ & $76(70,85)$ & $68(53,110)$ & 0.415 \\
\hline Hypotension on admission ( $\mathrm{n} / \mathrm{N})$ & $24(13.8 \%)$ & $3(50 \%)$ & $0.015^{*}$ \\
\hline
\end{tabular}

\section{RESULTS}

Our research covered the 180 patients with AMI treated by pPCI. Intrahospital mortality of these patients was $3.33 \%$ (6 of 180) of patients. The study included 128 (71.11\%) men and $52(28.89 \%)$ women. The average age of surviving patients was $58 \pm 11$ years, and in the group of the deceased patients it was $67 \pm 9$ years. The age differences between the groups showed a trend toward statistical significance $(\mathrm{p}=0.075, \mathrm{CI}=0.89-18.40, \mathrm{OR}=4.89)$.

Clinical and laboratory characteristics of the groups are listed in Table 1 and Table 2 the group of the deceased patients with AMI treated by pPCI, compared to the group

\begin{tabular}{|c|c|c|c|}
\hline Variables & Survivors $(\mathrm{N}=174)$ & Deceased $(\mathrm{N}=6)$ & $\mathrm{p}$ \\
\hline $\mathrm{Hgb} \pm \mathrm{SD},(\mathrm{g} / \mathrm{L})$ & $146 \pm 16$ & $140 \pm 27$ & 0.415 \\
\hline Le \pm SD $\left(\times 10^{9} / L\right)$ & $12 \pm 3$ & $13 \pm 4$ & 0.452 \\
\hline $\mathrm{K}+ \pm \mathrm{SD}(\mathrm{mmol} / \mathrm{L})$ & $4 \pm 0.5$ & $4 \pm 0.6$ & 0.666 \\
\hline $\operatorname{Tr} \pm \mathrm{SD}\left(\times 10^{9} / \mathrm{L}\right)$ & $255 \pm 72$ & $221 \pm 41$ & 0.257 \\
\hline Creatine kinase $(25,75$ per. $)(\mathrm{U} / \mathrm{L})$ & $2109(979,3723)$ & $2747(456,4887)$ & 0.987 \\
\hline Fibrinogen $(25,75$ per.) (g/L) & $3.9(3.3,4.7)$ & $3.5(2.1,8.0)$ & 0.500 \\
\hline Creatinine $(25,75$ per.) (umol/L) & $92(84,106)$ & $117(99,190)$ & $0.036^{*}$ \\
\hline Glycemia ( 25,75 per.) (mmol/L) & $7.4(6.0,9.8)$ & $8.9(7.4,12.5)$ & 0.189 \\
\hline Bundle branch block (n/N) & $14(8.0 \%)$ & $2(33.3 \%)$ & $0.032^{*}$ \\
\hline Rtg changes in the lungs $(n / N)$ & $22(12.6 \%)$ & $1(16.7 \%)$ & 0.752 \\
\hline Rtg enlarged cardiac silhouette $(\mathrm{n} / \mathrm{N})$ & $32(18.4 \%)$ & $1(16.7 \%)$ & 0.889 \\
\hline Rtg enlarged cardiac silhouette $(\mathrm{n} / \mathrm{N})$ & $32(18.4 \%)$ & $1(16.7 \%)$ & 0.889 \\
\hline
\end{tabular}

\begin{tabular}{|l|r|r|r|}
\hline \multicolumn{1}{|c|}{ Creatinine clearance $(\mathrm{ccs} / \mathrm{min})$} & Survivors $(\mathrm{N}=174)$ & Deceased $(\mathrm{N}=6)$ & $\mathrm{p}$ \\
\hline$>90 \mathrm{ccs} / \mathrm{min}$ & 58 & 1 & $>0.05$ \\
\hline $60-90 \mathrm{ccs} / \mathrm{min}$ & 83 & 1 & $>0.05$ \\
$<60 \mathrm{ccs} / \mathrm{min}$ & 33 & 4 & $<0.001^{*}$
\end{tabular}

of survivors, shown no statistically significant differences in frequency between the sexes, systolic and diastolic blood pressure, heart rate frequency, previously diagnosed diabetes; nei- ther did laboratory parameters: glucose values, hemoglobin, absolute leukocyte count, platelet count, fibrinogen, creatine kinase, or the difference in frequency of X-ray changes in the 


\begin{tabular}{|l|r|r|r|}
\multicolumn{1}{c|}{ Variables } & OR & \multicolumn{1}{c|}{$\mathrm{Cl}$} & \multicolumn{1}{c|}{$\mathrm{P}$} \\
\hline Killip $>1$ & 5.233 & $1.09-30.98$ & 0.038 \\
\hline Hypotension on admission & 6.250 & $1.19-32.78$ & 0.015 \\
\hline Creatinine & 1.01 & $1.0007-1.02$ & 0.036 \\
\hline Bundle branch block & 5.714 & $1.96-33.99$ & 0.032 \\
\hline Anamnesis smoking history/status & 0.523 & $0.45-0.60$ & 0.021 \\
\hline Age & 4.89 & $0.89-18.46$ & 0.075 \\
\hline
\end{tabular}

lungs and enlarged cardiac silhouette, and a anamnesis related to the existence of previous myocardial infarction and hypertension.

The heart failure rate according to Killip- $\mathrm{u}>1$ on admission, was more frequent in the deceased patients group and the difference was statistically significant $(\mathrm{p}=0.038, \mathrm{CI}=1.09$ 30.97, OR=5.23). A group of deceased patients had significantly more hypotension on admission $(\mathrm{p}=0.015, \mathrm{CI}=1.19-32.78, \mathrm{OR}=6.25)$. Creatinine values on admission in survivors group were in the range of $92(84,106) \mathrm{mmol} / \mathrm{L}$, while

\begin{tabular}{|l|r|r|r|}
\multicolumn{1}{c|}{ Variables } & OR & Cl & \multicolumn{1}{c|}{ P } \\
\hline Bundle branch block & 0.04 & 11.30 & $1.15-110.66$ \\
\hline Creatinine clearance $<60 \mathrm{ccs} / \mathrm{min}$ & 0.01 & 10.04 & $1.04-42.83$ \\
\hline Diabetes & 0.04 & 18.36 & $1.03-32.90$ \\
\hline Killip>1 & 0.04 & 4.95 & $1.01-22.36$ \\
\hline Hypotension & 0.05 & 1.04 & $1.00-1.15$ \\
\hline Age & 0.06 & 1.12 & $0.99-1.26$ \\
\hline
\end{tabular}

Table 5. Independent predictors of an early prognosis in patients with STEMI treated by $\mathrm{pPCl}$ - Multivariate analysis

OR - Odds ratio

$\mathrm{Cl}$ - 95\% Confidence interval p - level of statistical significance $(p<0.05$ statistically significant)

values in the deceased group were in the range of 117 deaths $(99,190) \mathrm{mmol} / \mathrm{L}$, this difference was statistically significant $(\mathrm{p}=0.036, \mathrm{CI}=1: 00$ to $1: 02, \mathrm{OR}=1.01$ ). Creatinine clearance less than $60 \mathrm{ccs} / \mathrm{min}$ had been found in 4 patients in the deceased group, and 33 patients in the survivors group, stated difference was highly statistically significant $(p<0.001)$. Within the group of the deceased patients significantly more frequent ECG changes were observed in terms of acute bundle branch block ( $\mathrm{p}=0.032$, $\mathrm{CI}=1.96-33.99, \mathrm{OR}=5.71)$. Also, these patients often had a history of hyperlipidemia ( $\mathrm{p}=0.044, \mathrm{CI}=1.19-60.42, \mathrm{OR}=6.91)$, and they were less likely to have been smokers $(\mathrm{p}=0.021$, $\mathrm{CI}=0.45-0.60, \mathrm{OR}=0.52$ ) (Table 4). Logistic regression analysis of clinical and laboratory variables registered on admission of patients has shown that the independent predictors of an early adverse prognosis are: diabetes, Killip $>1$ on admission, hypotension on admission, creatinine clearance $<60 \mathrm{ccs} / \mathrm{min}$ (Table 3 ), acute bundle branch block, whereas the age of the patient showed a trend toward statistical significance (Table 5).

\section{DISCUSSION}

Our study showed that the degree of cardiac insufficiency according to Killip on admission (Killip>1), the occurrence of hypotension during hospitalization, creatinine values on admission, electrocardiographic recording of acute bundle branch block, as well as the presence of hyperlipidemia, represent the negative predictive factors in univariate analysis. In multivariate analysis, independent indicators of early mortality were diabetes, Killip $>1$ on admission, hypotension, creatinine clearance $<60 \mathrm{ccs} / \mathrm{min}$, acute bundle branch block; as the age of the patients showed a trend toward statistical significance.

Intrahospital mortality of patients in our study was $3.33 \%$, and it is consistent with the data from other Centers where the mortality was $2-5 \%$, but this percentage increases significantly in higher risk rates patients [4].

Bilkova et al. [5] and other authors' [6] researches showed that early prognosis of patients with STEMI treated by pPCI depends on clinical parameters of the so-called shock index (defined as the value of heart rate frequency and blood pressure on admission) and that the highest mortality rate was for the patients with cardiogenic shock (20.3\%), which is consistent with the results of our study which shows that the degree of heart failure according to Killip $>1$ (on patient's admission), is a
Table 4. Predictors of early prognosis in patients with AMl treated by $\mathrm{pPCl}$ - Univariate analysis

OR - Odds ratio

$\mathrm{Cl}$ - 95\% Confidence interval p - level of statistical significance $(p<0.05$ statistically significant) 
negative predictive factor for an adverse early prognosis in multivariate analysis. A study which followed 30-day and one-year mortality of patients with AMI treated by this method showed that Killip $>1$ at admission [7] was a predictor of early as well as one-year mortality.

Many studies suggest that there are significant gender differences in the outcome of patients treated by pPCI, with an adverse prognosis for the female gender, where the mortality rate of women was caused by the occurrence of heart insufficiency and cardiogenic shock [10] in the highest percentage. D'Ascenzo et al. indicate a higher incidence of death among females treated by pPCI, which is explained by the fact that women are usually elderly patients; furthermore, in the study group women significantly more often suffered from diabetes mellitus [11]. But after 60 months of observation, a difference in death outcome between the sexes was not noted.

Our study shows that the age of patients is an independent prognostic factor, i.e. with advanced age increases the risk of early adverse outcomes in patients treated by pPCI, which is consistent with literature data [7, $8,12]$. Studies dealing with risk assessment and adverse events after pPCI using scoring systems [13-16] give age a significant impact as predictor of early adverse outcome, which was confirmed in a meta-analysis that dealt with the comparison of these studies [16]. On the other hand Teplitsky et al. analysis showed that in patients older than 90 years, pPCI was associated with low mortality in clinically stable patients, while clinically unstable patients had much worse prognosis in a six-month followup [17]. Furthermore, a study of 102 patients older than 75 years indicates that the pPCI is safe and useful method of treatment, which contributes to the reduction of intrahospital and one-year mortality in these patients [18].

Glycemia on admission was analyzed in many studies as a predictive factor in early, as well as late prognosis. In patients with diabetes, higher serum glucose level is associated with adverse prognosis and a higher mortality rate $[7,8,14,15,19-24]$. In patients who were not suffering from diabetes has been shown that high glucose level on admission has a significant role as an independent predictive factor for early and late prognosis [21]. Therefore, patients who don't have diabetes, with high glucose levels on admission, have 2.8 times higher death rate after 28 days of monitoring compared to the group of patients with diabetes mellitus with higher admission glycemia levels [22]. In our study, glucose levels on admission was not as significant predictive factor of early adverse prognosis, which could be explained by the relatively small number of patients involved in research. However, the presence of diabetes correlated with a significantly adverse prognosis in comparison with the patients who don't have diabetes, which is consistent with other studies.

Creatinine value on admission in patients with AMI is an independent factor of early mortality, which is consistent with the data obtained in literature [20, 23-26], where serum creatinine higher than $1.5 \mathrm{mg} /$ $\mathrm{dL}$ showed a significant indication of adverse prognosis. In one of stated works, the high uric acid levels, and renal failure correlated with adverse prognosis [25]. Zhang et al, showed that the high creatinine levels on admission (>115 micromol/l) in patients with STEMI treated by pPCI with DES stent implantation, was independent predictor of MACE (major cardiac events adverse) in the first 90 days. Elevated levels of creatinine indicate abnormal hemodynamic status [27]. Our study showed that the mortality was recorded significantly more in patients with creatinine clearance values less than $60 \mathrm{ccs} / \mathrm{min}$, which represents an independent predictive factor of intrahospital mortality of these patients (Table 3 )

Our results indicate that hypotension is the factor of adverse prognosis, which may be explained by the higher incidence of heart failure (higher rate according to Killip) and cardiogenic shock in these patients, which represent negative prognostic factors. These results are consistent with other studies $[5,13$, $14,16]$.

Acute bundle branch block was an independent predictor of intrahospital mortality in multivariate analysis, which is consistent with results of other researches $[5,26]$. Acute bundle branch block in patients with AMI is associated with the size of infarction zone, increased frequency of pulmonary edema (Killip III) and cardiogenic shock (Killip IV) [14-16, 27].

The values of hemoglobin, creatine kinase, leukocyte count, potassium, fibrinogen, platelet count, as well as X-ray changes in the lungs and heart in our study did not show significance as early prognostic factors, which 
is not consistent with data from the literature [28-30]. Numerous studies suggest that predictors of early and later mortality [14-16, $23,32,33]$, are low hemoglobin (anemia) and elevated inflammatory markers (leukocyte counts, high neutrophil-lymphocyte ratio, CRP). Discordance between the literature data and results of our studies in these clinical and laboratory parameters can be explained by the fact that this retrospective study was limited by the small number of patients included.

Our research has shown that the group of deceased patients had significantly fewer smokers. The phenomenon of so-called "Smoker's paradox" has been investigated in other studies where a lower mortality after pPCI precisely in a group of active and former smokers, as compared with a group of nonsmokers, was explained by greater influence of other risk factors on the occurrence of AMI than the smoking status, as well as the fact that with smokers AMI occurs almost a decade earlier [8, 34].

The results obtained in this study are consistent with the results of other studies that were conducted on significantly higher number of patients. Predictors of early mortality obtained in this study represent significant parameters in determining the scores [13-16] of patients with STEMI treated by pPCI, and are used in order to achieve adequate clinical evaluation of these patients. Adequate risk assessment early after pPCI can enable the application of appropriate measures and procedures that would be aimed to reduce or prevent unwanted course and outcome of the illness.

\section{Study limitations}

The number of deceased is very small. With such small number of these cases their representivity is questionable. Also, logistic model validation and/or bootstrapping is not performed.

\section{CONCLUSION}

Our study showed that diabetes, Killip $>1$ on admission, hypotension, creatinine clearance $<60 \mathrm{ccs} / \mathrm{min}$ and acute bundle branch block represent the independent clinical and laboratory parameters of early mortality in patients with STEMI treated by pPCI.

\section{REFERENCES}

1. Nedeljković S, Kanjuh V ,Vukotić M. Kardiologija. Beograd, 2009.

2. Ferrari R, Lettino M, Ceconi C, Tavazzi L. STEMI 128 questions nad answers. 2007.

3. Obradović V. Akutni infarkt miokarda-klinika, dijagnostika, lečenje. Beograd, 2007.

4. Keeley CE, Hillis LD. Primary PCI for Myocardial Infarction with ST-Segment Elevation. N Engl J Med 2007; 356:47-54.

5. Bilkova D, Widimsky P, Dvorak J, Budesinsky T, Lisa L. Shock index: a simple clinical parameter for quick mortality risk assessment in acute myocardial infarction. Chest 2008; 134(4):2003-2008.

6. Tungsubutra W, Tresukosol D, Krittayaphong R, Panchavinnin P, Phankingtongkhum R, Chotnaiwattarakul C. Primary percutaneous transluminal coronary intervention compared with intravenous thrombolysis in patients with ST segment elevation myocardial infarction. J Med Assoc Thai 2007; 90(4):672-678.

7. Rasoul S, Ottervanger JP, de Boer MJ, Dambrink JH, Hoorntje JC, Marcel Gosselink AT, Zijlstra F, Suryapranata H, van 't Hof AW. Predictors of 30-day and 1-year mortality after primary percutaneous coronary intervention for ST-elevation myocardial infarction. Coronary Artery Disease 2009; 20:415421.

8. Verouden NJ, Haeck JD, Kuijt WJ, Meuwissen M, Koch KT, Henriques JP, Baan J, Vis MM, Piek JJ, Tijssen JG, de Winter RJ. Clinical and Angiographic Predictors of ST-Segment Recovery after Primary Percutaneous Coronary Intervention. Am J Cardiol 2010; 105:1692-1697.

9. Vučinić ZM, Djukić LjC. The Regulation of Clinical Trials in the Republic of Serbia. Hospital Pharmacology - International Multidisciplinary Journal. 2015; 2(3):322-327. ( www.hophonline.org )

10. Nowakowska-Arendt A, Grabczewska Z, Koziński $M$, Sukiennik A, Swiatkiewicz I, Grześk G, Radomski M, Bogdan M, Kochman W, Kubica J. Gender differences and in-hospital mortality in patients undergoing percutaneous coronary interventions. Kardiol Pol 2008; 66(6):632-639.

11. D’Ascenzo F, Gonella A, Quadri G, Longo G, Biondi-Zoccai G, Moretti C, Omedè P, Sciuto F, Gaita F, Sheiban I. Comparison of Mortality Rates in Women Versus Men Presenting With ST-Segment Elevation Myocardial Infarction. Am J Cardiol 2011; 107:651- 654 .

12. Hiew C, Williams T, Hatton R, Narasimhan $S$, O'Connor S, Baker F, McElduff P, Attia J, Collins N. Influence of Age on Long-Term Outcome After Emergent Percutaneous Coronary Intervention for STElevation Myocardial Infarction. J. Invasive cardiol 2010; 22(6): 273-277. 
13. Tjandrawidjaja MC, Fu Y, Westerhout CM, Wagner GS, Granger CB, Armstrong PW. Usefulness of the QRS Score as a Strong Prognostic Marker in Patients Discharged After Undergoing Primary Percutaneous Coronary Intervention for ST-Segment Elevation Myocardial Infarction. Am J Cardiol 2010; 106:630-634.

14. Mrdovic I, Savic L, Krljanac G, Asanin M, Perunicic J, Lasica R, Marinkovic J, Kocev N, Vasiljevic Z, Ostojic M. Predicting 30-day major adverse cardiovascular events after primary percutaneous coronary intervention. The RISK-PCI score. Int J Cardiol (2011), doi:10.1016/j.ijcard.2011.05.071.

15. Mrdovic I, Savic L, Perunicic J, Asanin M, Lasica R, Marinkovic J, Vasiljevic Z, Ostojic M. Development and Validation of a Risk Scoring Model to Predict Net Adverse Cardiovascular Outcomes after Primary Percutaneous Coronary Intervention in $\mathrm{Pa}$ tients Pretreated with $600 \mathrm{mg}$ Clopidogrel: Rationale and Design of the RISK-PCI Study. J Interven Cardiol 2009; 22:320-328.

16. Martinoni A, De Servi S, Politi A, Palmerini T, Musumeci G, Ettori F, Zanini R, Piccaluga E, Sangiorgi D, Repetto A, D’Urbano M, Castiglioni B, Fabbiocchi F, Onofri M, Lauria G, De Cesare N, Sangiorgi G, Lettieri C, Belli G, Poletti F, Pirelli S, Klugman S. Defining high-risk patients with ST-segment elevation acute myocardial infarction undergoing primary percutaneous coronary intervention: A comparison among different scoring systems and clinical definitions. Int J Cardiol (2011), doi:10.1016/j. ijcard.2010.12.007.

17. Teplitsky I, Assali A, Lev E, Brosh D, Vaknin-Assa $\mathrm{H}$, Kornowski R. Results of percutaneous coronary interventions in patients > or $=90$ years of age. Catheter Cardiovasc Interv 2007; 70(7):937-943.

18. Zhang $Q$, Zhang RY, Zhang JS, Hu J, Yang ZK, Zheng AF, Zhang $X$, Shen WF. Outcomes of primary percutaneous coronary intervention for acute ST-elevation myocardial infarction in patients aged over 75 years. Chin Med J (Engl) 2006; 119(14):11511156

19. Gasior M, Stasik-Pres G, Pres D, Lech P, Gierlotka M, Lekston A, Hawranek M, Tajstra M, Kalarus Z, Poloński L. Relationship between blood glucose on admission and prognosis in patients with acute myocardial infarction treated with percutaneous coronary intervention. Kardiol Pol 2007; 65(9):10311038.

20. Straumann E, Kurz DJ, Muntwyler J, Stettler I, Furrer M, Naegeli B, Frielingsdorf J, Schuiki E, Mury $\mathrm{R}$, Bertel O, Spinas GA. Admission glucose concentrations independently predict early and late mortality in patients with acute myocardial infarction treated by primary or rescue percutaneous coronary intervention. Am Heart J 2005; 150(5):1000-1006.

21. Valente S, Lazzeri C, Vecchio S, Giglioli C, Margheri M, Bernardo P, Comeglio M, Chiocchini S, Gensini GF. Predictors of in-hospital mortality after percutaneous coronary intervention for cardiogenic shock. Int J Cardiol 2007; 114(2):176-182.
22. Beck JA, Meisinger C, Heier M, Kuch B, Hörmann A, Greschik C, Koenig W. Effect of Blood Glucose Concentrations on Admission in Non-Diabetic Versus Diabetic Patients With First Acute Myocardial Infarction on Short- and Long-Term Mortality (from the MONICA/KORA Augsburg Myocardial Infarction Registry). Am J Cardiol 2009; 104:1607-1612.

23. Kruk M, Przyłuski J, Kalińczuk L, Pregowski J, Kaczmarska E, Petryka J, Kłopotowski M, Kepka C, Chmielak Z, Demkow M, Ciszewski A, Piotrowski W, Karcz M, Bekta P, Witkowski A, Ruzyłło W. Clustering of admission hyperglycemia, impaired renal function and anemia and its impact on in-hospital outcomes in patients with ST-elevation myocardial infarction. Atherosclerosis 2010; 209:558-564.

24. Corrada E, Cappelleri A, Belli G, Genovese S, Barbaro C, Gasparini G, Pagnotta P, Rossi M, Zavalloni $D$, Presbitero P. Admission glycemia and markers of inflammation are independent outcome predictors in primary $\mathrm{PCl}$ in non-diabetic patients. Minerva Cardioangiol 2008; 56(5):445-452.

25. Assali AR, Brosh D, Ben-Dor I, Solodky A, Fuchs $S$, Teplitsky I, Kornowski R. The impact of renal insufficiency on patients' outcomes in emergent angioplasty for acute myocardial infarction. Catheter Cardiovasc Interv 2007; 69(3):395-400.

26. Zhang Q, Zhang RY, Shen J, Zhang JS, Hu J, Yang ZK, Zhang X, Zheng AF, Shen WF. Impact of admission creatinine level on clinical outcomes of patients with acute ST-elevation myocardial infarction undergoing primary percutaneous coronary intervention with drug-eluting stent implantation. Chinese Medical Journal 2008; 121(23):2379-2383.

27. Mijajlović V, Mrdović I, Ilić M, Ašanin M, Srdić $M$, Rajić D. Prognostički značaj akutnog bloka grane kod bolesnika sa akutnim infarktom miokarda. Vojnosanit Pregl 2008; 65(10):733-737.

28. Garot P, Bendaoud N, Lefèvre T, Morice MC. Favourable effect of statin therapy on early survival benefit at the time of percutaneous coronary intervention for ST-elevation myocardial infarction and shock. Eurolntervention 2010; 6(3):350-355.

29. Vis MM, Sjauw KD, van der Schaaf RJ, Koch KT, Baan J Jr, Tijssen JG, Piek JJ, de Winter RJ, Henriques JP. Prognostic value of admission hemoglobin levels in ST-segment elevation myocardial infarction patients presenting with cardiogenic shock. Am J Cardiol 2007; 99(9):1201-1202.

30. Mariani M, Fetiveau R, Rossetti E, Poli A, Poletti F, Vandoni P, D’Urbano M, Cafiero F, Mariani G, Klersy C, De Servi S. Significance of total and differential leucocyte count in patients with acute myocardial infarction treated with primary coronary angioplasty. Eur Heart J 2006; 27(21):2511-2515.

31. Sezer M, Okcular I, Goren T, Oflaz H, Nisanci $\mathrm{Y}$, Umman B, Mercanoglu F, Bilge AK, Meric M, Umman $S$. Association of haematological indices with the degree of microvascular injury in patients with acute anterior wall myocardial infarction treated with primary percutaneous coronary intervention. 
Heart 2007; 93(3):313-318.

32. Cho KH, Jeong MH, Ahmed K, Hachinohe D, Choi HS, Chang SY, Kim MC, Hwang SH, Park KH, Lee MG, Ko JS, Sim DS, Yoon NS, Yoon HJ, Hong YJ, Kim KH, Kim JH, Ahn Y, Cho JG, Park JC, Kang JC. Value of Early Risk Stratification Using Hemoglobin Level and Neutrophil-to-Lymphocyte Ratio in Patients With STElevation Myocardial Infarction Undergoing Primary Percutaneous Coronary Intervention. Am J Cardiol 2011; 107:849-856.

33. Bolińska S, Sobkowicz B, Zaniewska J, Chlebińska I, Boliński J, Milewski R, Tycińska A, Musiat W. The significance of anaemia in patients with acute STelevation myocardial infarction undergoing primary percutaneous coronary intervention. Kardiol Pol 2011; 69(1):33-39.

34. Weisz G, Cox DA, Garcia E, Tcheng JE, Griffin JJ, Guagliumi G, Stuckey TD, Rutherford BD, Mehran R, Aymong E, Lansky A, Grines CL, Stone GW. Impact of smoking status on outcomes of primary coronary intervention for acute myocardial infarctionthe smoker's paradox revisited. Am Heart J 2006; $150(2): 358-364$. 


\title{
Klinički i laboratorijski parametri ranog mortaliteta bolesnika sa akutnim infarktom miokarda lečenih primarnom perkutanom koronarnom intervencijomi
}

\author{
Dušan P. Ružičić ${ }^{1}$, Milijana M. Ružičić ${ }^{1}$, Igor B. Mrdović ${ }^{2}$ \\ ${ }^{1}$ Opšta bolnica Valjevo, Odeljenje interne medicine - kardiologija, Valjevo, Srbija \\ ${ }^{2}$ Klinički centar Srbije, Klinika za urgentnu internu medicinu, Odeljenje za kardiologiju, Beograd, Srbija
}

\section{KRATAK SADRŽAJ}

Uvod: Primarna perkutana koronarna intervencija $(\mathrm{pPCl})$ postala je najvažnija strategija u reperfuziji pacijenata sa ST- elevacijom u infarktu miokarda (STEMI). Dosadašnje studije su pokazale da se određeni klinički i laboratorijski parametri mogu povezati sa ranim mortalitetom kod pacijenata sa akutnim infarktom miokarda lečenih primarnom $\mathrm{PCl}$.

Cilj: Cilj našeg istraživanja bio je da se procene klinički i laboratorijski pokazatelji rane nepovoljne prognoze naših pacijenata sa STEMI, a koji su lečeni primarnom $\mathrm{PCI}$. Materijal i metode: Populacija naše IV faze, akademske, opservacione, retrospektivne studije preseka, obuhvata ukupno 180 uzastopnih pacijenata (128 muškaraca i 52 žene), starosti od 18 godina i više, a koji su ispoljili kliničke i elektrokardiografske znake akutnog STEMI u roku od 12 sati nakon pojave simptoma. Analizirali smo parametre koji su registrovani u sistemu baze podataka koronarne jedinice Urgentnog centra.

Rezultati: Prosečna starost preživelih pacijenata bila je $58 \pm 11$ godina i $67 \pm 9$ godina u grupi umrlih pacijenata, iako razlika između grupa nije bila statistički značajna ( $p$ $=0.075)$. U grupi pacijenata koji nisu preživeli bilo je značajno više hipotenzije na prijemu ( $p=0.015)$ i akutnog bloka grane na EKG-u $(p=0.032)$, kreatinin je bio viši na prijemu ( $p=0.036)$, kao i veća učestalost hiperlipidemije $(p=0.044)$ i klirensa kreatinina ispod $60 \mathrm{ccs} / \min (p<0,001)$, zatim češća je bila pojava Killip > 1 srčane insuficijencije na prijemu $(p=0.038)$, ali je učestalost pušača bila značajno manja $(p=0.021)$. Prediktori ranog nepovoljnog događaja u multivarijantnoj analizi bili su: akutni blok grane, dijabetes, Killip $>1$ na prijemu, hipotenzija na prijemu i klirens kreatinina ispod $60 \mathrm{ccs} / \mathrm{min}$.

Zaključak: Naša studija je pokazala da akutni blok grane, dijabetes, Killip $>1$ srčane insuficijencije na prijemu, hipotenzija na prijemu, kao i klirens kreatinina ispod 60 ccs / min, predstavljaju nezavisne kliničke i laboratorijske prediktore ranog mortaliteta kod pacijenata sa STEMI lečenih primarnom PCI.

Ključne reči: $\mathrm{PCl}$, infarkt miokarda, rani mortalitet 